\title{
LOW-FLOW WATER-QUALITY CHARACTERIZATION OF THE GORE CREEK WATERSHED, UPPER COLORADO RIVER BASIN, COLORADO, AUGUST 1996
}

\author{
-Kirby H. Wynn and Norman E. Spahr
}

\section{HIGHLIGHTS}

$\checkmark$ The stable summer low-flow period is a time of good water quality in the watershed-dissolved-oxygen concentrations are high, and constituent concentrations are low.

$\checkmark$ Nine of 17 trace elements were detected. Concentrations were related to weathering of crystalline and sedimentary rocks rather than to urban or recreational land uses.

$\checkmark$ Although four U.S. Environmental Protection Agency (USEPA) trace-element priority pollutants were detected in stream samples, they were present only in low concentrations.

$\checkmark$ Nutrient concentrations did not exceed stream standards, but were somewhat elevated downstream through the Town of Vail.

\section{INTRODUCTION}

The Upper Colorado River Basin (UCOL) is one of 59 National Water-Q uality Assessment (NAWQA) study units designed to assess the status and trends of the Nation's water quality (Leahy and others, 1990). The UCOL study unit began operation in 1994, and surface-water-quality data collection at a network of 14 sites began in October 1995 (A podaca and others, 1996; Spahr and others, 1996).

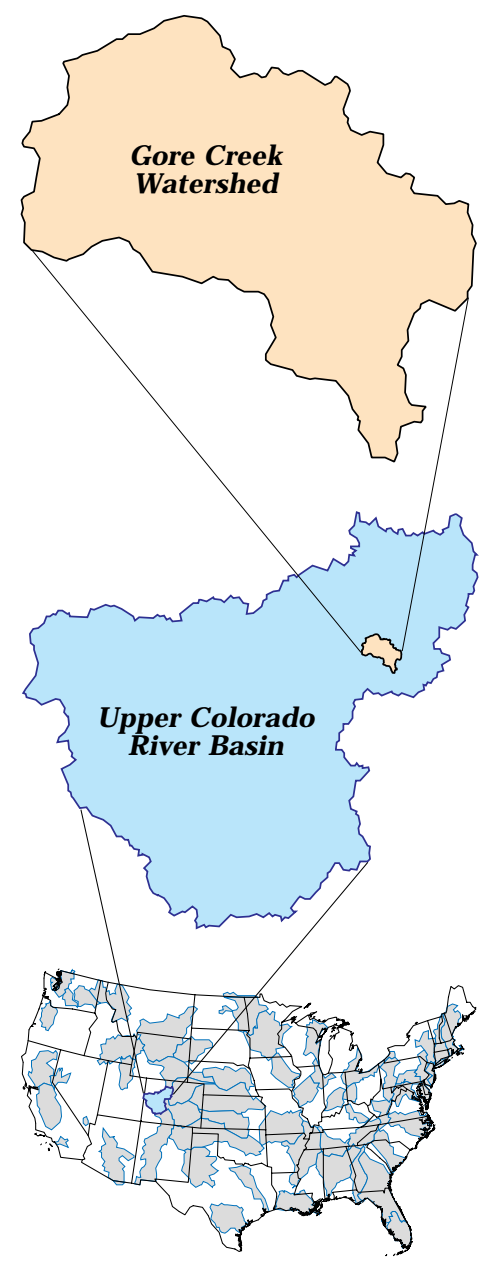

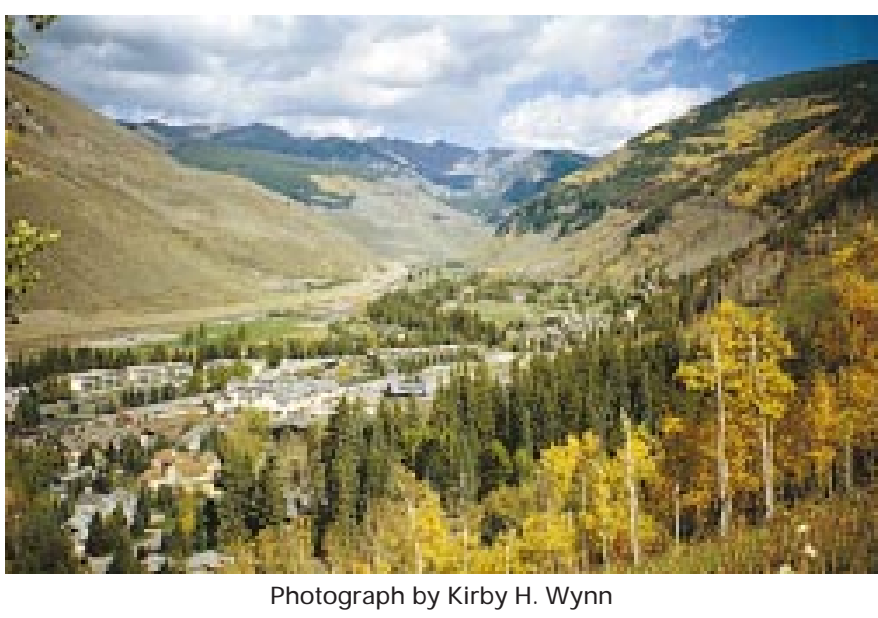

information about water quality resulting from land use, but a synoptic sampling is needed to determine the distribution and sources of water-quality constituents at one point in time.

In August 1996, a low-flow synoptic sampling for analyses of water-quality properties and constituents at sites in the Gore Creek watershed was done by the U.S. Geological Survey, in cooperation with the Town of Vail, Eagle River Water and Sanitation District, Upper Eagle River Water Authority, and Northwest Colorado Council of Governments, to evaluate the water quality of Gore Creek.

Gore Creek, which flows through Vail, Colorado, originates in pristine alpine headwaters and is designated a gold-medal trout fishery. The creek drains an area of about 102 square miles and is a tributary to the Eagle River. Gore Creek at the mouth near Minturn (site 13 in fig. 1) is one of the 14 sites in the UCOL network. This site was selected to evaluate water quality resulting from urban development and recreational land use.

The Gore Creek watershed has undergone rapid land-use changes since the 1960's as the Vail area shifted from traditional mountain ranchlands to a four-season resort community. Residential, recreational, commercial, and transportation development continues near Gore Creek and its tributaries to support the increasing permanent and tourist population of the area. Interstate 70 runs through the watershed from Vail Pass near site 14, along the eastern side of Black Gore Creek, and along the northern side of the main stem of Gore Creek to the mouth of the watershed (fig. 1). A major local concern is how increasing urbanization/ recreation affects the water quality, gold-medal trout fishery, and aesthetic values of Gore Creek. An evaluation of the spatial characteristics of water quality in the watershed upstream from site 13 at the mouth of Gore Creek (fig. 1) can provide local water and land managers with information necessary to establish water policy and make land-use planning decisions to maintain or improve water quality. $\mathrm{H}$ istorical data collected at the mouth of Gore Creek provide
The August low-flow period can be important from water-quality and stream ecology perspectives. There is less water available to dilute any contaminants entering the streams, and stream temperatures are highest during August. Physical habitat for aquatic plants and animals is smaller than during most other times of the year. To address these more extreme water-quality and ecological conditions, the synoptic sampling was conducted during the summer low-flow period.

\section{Specific objectives of this sampling included:}

1. Establish a current data set representing the spatial characteristics of low-flow waterquality conditions in the Gore Creek watershed, and

2. Develop some understanding of land-use and water-quality relations in the watershed.

This fact sheet presents hydrologic background information and an analysis of general water-quality properties and constituents, trace elements, and nutrients collected in water samples during low-flow synoptic sampling of the Gore Creek watershed.

The U.S. Geological Survey also is conducting a study of the algae and macroinvertebrate communities and physical habitat of streams in the Gore C reek watershed during low flow. This study is designed to provide information about land-use and stream ecology relations in the watershed. 


\section{DATA COLLECTION}

Water-quality samples were collected from August 19 through August 23, 1996, at 24 sites (fig. 1). The sites included 4 on Black Gore Creek, 13 on Gore Creek, and 7 at the mouths of tributaries. Sites 1 through 13 are on the main stem of Gore Creek and were chosen to represent any effects of urban land use on water quality as water flows from the headwaters through the Town of Vail. Sites 5 and 7 bracket the golf course. The wastewater-treatment-plant outfall is located between sites 8 and 9, upstream from the confluence of Red Sandstone and Gore Creeks. Sites 16 and 1 (Polk and Gore Creeks) represent background (undeveloped land use) conditions, whereas sites 19, 20, 21, and 23

(Bighorn, Pitkin, Booth, and Middle C reeks) also generally represent background conditions, but are relatively close to Interstate 70 and some minor land development.

Water samples were collected using an equal-width interval method, and samples were processed using standard NAWQA surface-water protocols (Shelton, 1994). A nalytical results from the synoptic sampling are reported in Crowfoot and others (1996). Synoptic-sampling results included in Crowfoot and others (1996), but not summarized in table 1 are streamflow, alkalinity, and concentrations of major ions (calcium, chloride, fluoride, magnesium, potassium, silica, sodium, and sulfate).

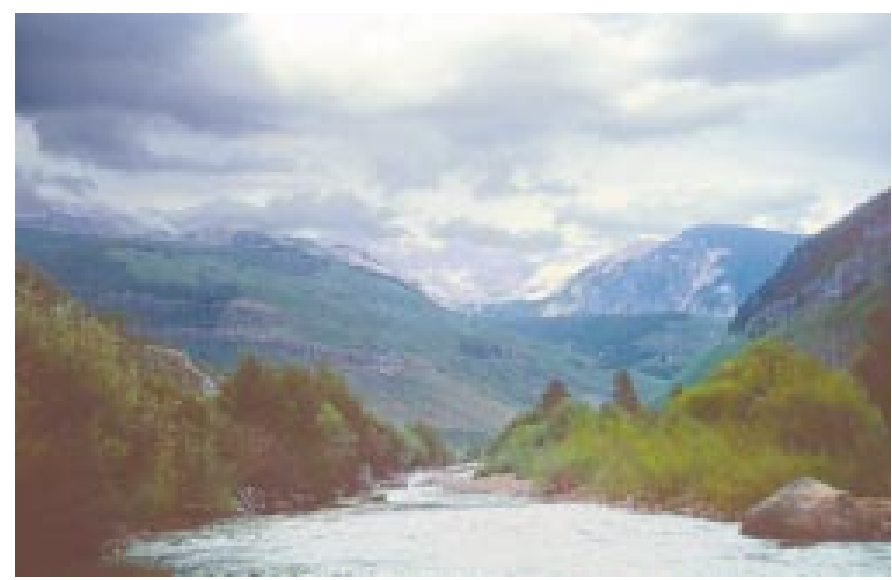

Photograph by Richard J . Szmajter

\section{RESULTS}

Selected analytical results for the synoptic sampling are summarized in table 1 . The lowest applicable stream-quality standards have been calculated for Gore Creek using the methods of the Colorado Department of Health (1996) and are listed for properties and constituents in table 1. The stream-quality standards are the chronic aquatic-life, acute aquatic-life, or drinking-water standards, if available.

\section{HYDROLOGY}

The synoptic sampling was conducted during stable, low-flow conditions. Streamflow at the mouth of Gore Creek during the synopticsampling period (August 19-23) was near the low flow for water year 1996, gradually declining from 64 to 43 cubic feet per second ( $\mathrm{ft}^{3} / \mathrm{s}$ ) (fig. 2). No significant precipitation occurred during the sampling period or in the week prior to sampling.

Flow from the primary point source, the wastewater-treatment plant, accounted for less than 10 percent of the streamflow at the mouth of Gore Creek (Caroline Byus, Eagle River Water and Sanitation District, written commun., 1997); therefore, dilution had a strong mitigating effect on any chemical constituents discharging into Gore Creek from this point source during the synoptic sampling. No additional point sources were observed near sampling sites during the synoptic-sampling period.

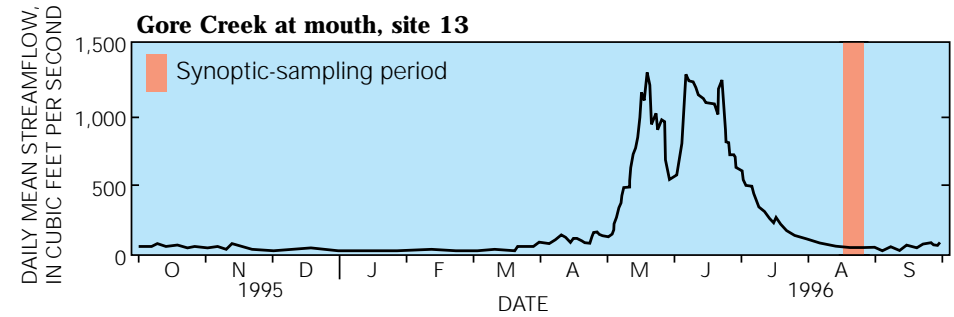

Figure 2.-Streamflow during the synoptic period compared to water year 1996 hydrograph.

\section{GENERAL WATER QUALITY}

Water in the Gore Creek watershed generally was of good quality at synoptic-sampling sites. Concentrations of dissolved oxygen and dissolved solids, pH, specific conductance, and suspended-sediment concentrations, which are indicators of overall stream water quality, did not exceed applicable stream standards. Dissolved-oxygen concentrations were near saturation at all sites. Dissolved-solids concentrations generally were low in Gore Creek (fig. 3), but gradually increased in a downstream direction from 29 milligrams per liter ( $\mathrm{mg} / \mathrm{L}$ ) at site 1 (background site) to $165 \mathrm{mg} / \mathrm{L}$ at the mouth of Gore Creek. Tributaries draining sedimentary rock formations in undeveloped areas and in the ski area probably contributed most of this increase in dissolved-solids concentrations. Suspended-sediment concentrations were very low at all sites, ranging from 1 to $3 \mathrm{mg} / \mathrm{L}$ (table 1 ).

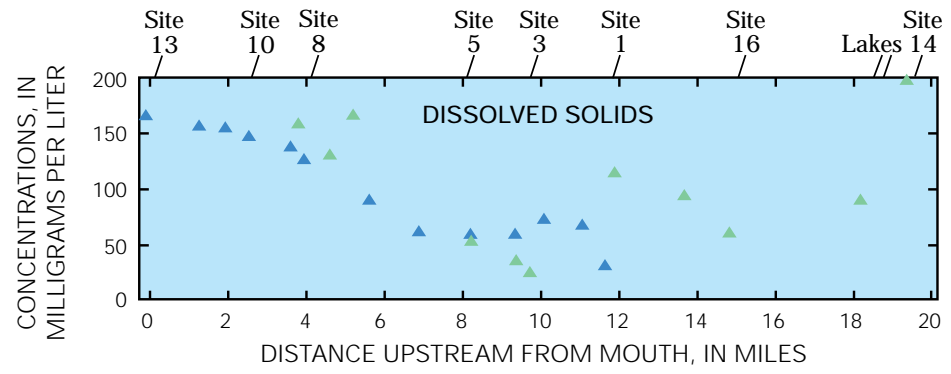

Figure 3.-Concentrations of selected constituents. Symbol colors correspond to explanation in figure 1. 


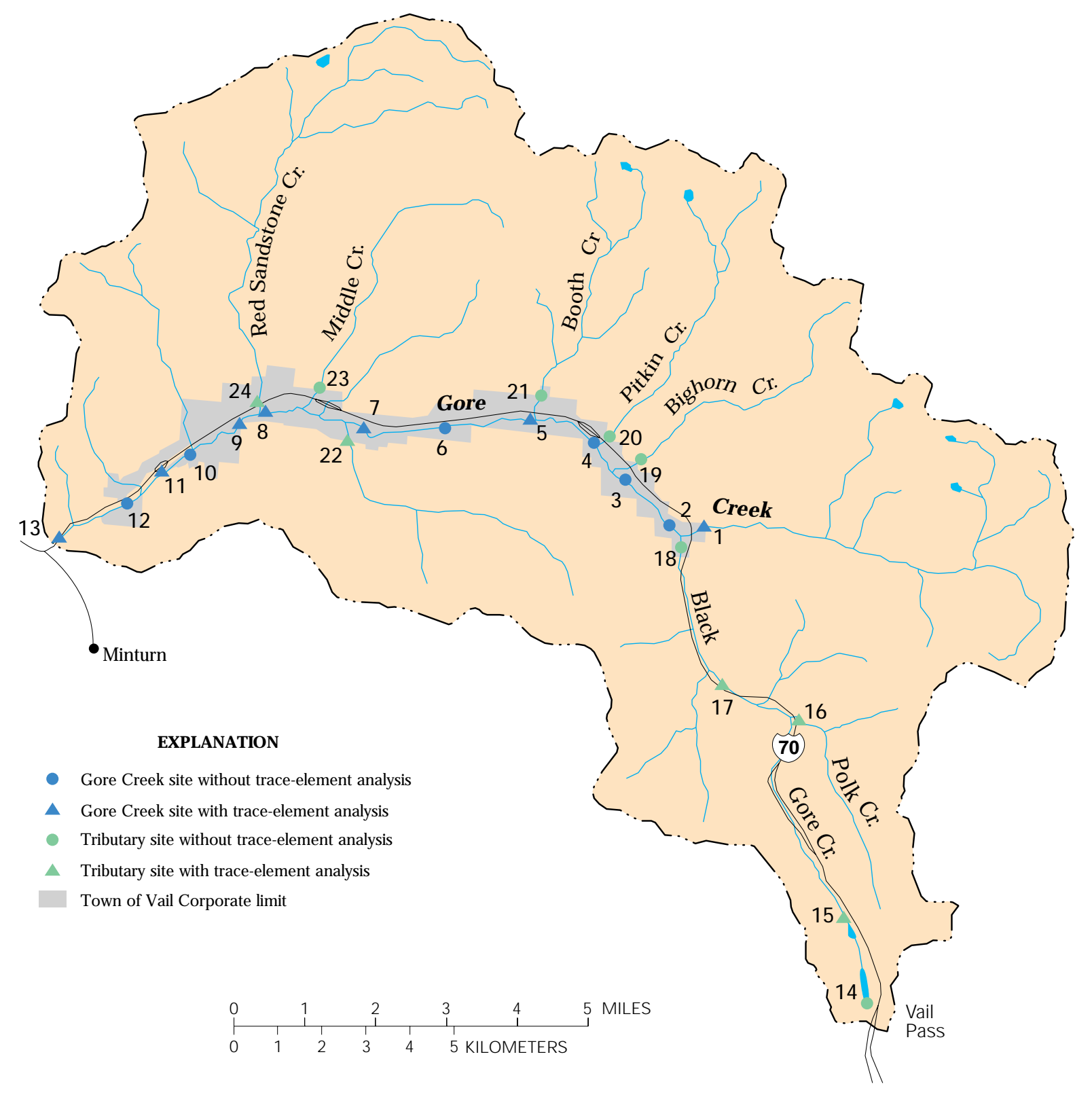

Figure 1.-Gore Creek watershed sampling sites. 
Table 1.-- Summary of water-quality analyses for water samples collected in the Gore Creek watershed, August 1996

[USEPA, U.S. Environmental Protection Agency; *, no detections greater than laboratory reporting limit; — , no data; mg/L, milligrams per liter; ${ }^{\circ} \mathrm{C}$, degrees Celsius; $\mu \mathrm{S} / \mathrm{cm}$, microsiemens per centimeter at 25 degrees Celsius; $\mu \mathrm{g} / \mathrm{L}$, micrograms per liter; $\mathrm{N}$, nitrogen; $\mathrm{P}$, phosphorus]

\begin{tabular}{|c|c|c|c|c|}
\hline $\begin{array}{c}\text { Property } \\
\text { or constituent }\end{array}$ & $\begin{array}{c}\text { Number of } \\
\text { detections/total } \\
\text { number of samples }\end{array}$ & $\begin{array}{l}\text { Range of detected } \\
\text { concentrations }\end{array}$ & $\begin{array}{l}\text { Laboratory } \\
\text { reporting limit }\end{array}$ & $\begin{array}{l}\text { Stream } \\
\text { standard }^{1}\end{array}$ \\
\hline \multicolumn{5}{|c|}{ General water quality } \\
\hline Dissolved oxygen, mg/L & $24 / 24$ & $6.7-9.0$ & - & 6.0 \\
\hline Dissolved solids, mg/L (calculated) & $24 / 24$ & $26-199$ & - & - \\
\hline $\mathrm{pH}$, standard units & $24 / 24$ & $7.5-8.9$ & - & $6.5-9.0$ \\
\hline Specific conductance, $\mu \mathrm{S} / \mathrm{cm}$ & $24 / 24$ & $45-397$ & - & - \\
\hline Suspended sediment, $\mathrm{mg} / \mathrm{L}$ & $12 / 24$ & $1-3$ & - & - \\
\hline Water temperature, ${ }^{\circ} \mathrm{C}$ & $24 / 24$ & $7-16$ & - & - \\
\hline \multicolumn{5}{|c|}{ Trace-element priority pollutants ${ }^{2}$, dissolved $(\mu \mathrm{g} / \mathrm{L})$} \\
\hline Arsenic & $0 / 12$ & $*$ & 1 & 350 \\
\hline Cadmium & $0 / 12$ & $*$ & 1 & 1.1 \\
\hline Chromium & $4 / 12$ & $2-3$ & 1 & ${ }^{3} 50$ \\
\hline Copper & $3 / 12$ & $1-2$ & 1 & 11.8 \\
\hline Lead & $0 / 12$ & $*$ & 1 & 3.9 \\
\hline Nickel & $9 / 12$ & $1-3$ & 1 & 96 \\
\hline Silver & $0 / 12$ & $*$ & 1 & 0.08 \\
\hline Zinc & $6 / 12$ & $1-5$ & 1 & 106 \\
\hline \multicolumn{5}{|c|}{ Other trace elements, dissolved $(\mu \mathrm{g} / \mathrm{L})$} \\
\hline Aluminum & $12 / 12$ & $3-10$ & 1 & 87 \\
\hline Antimony & $0 / 12$ & $*$ & 1 & ${ }^{3} 6$ \\
\hline Barium & $12 / 12$ & $19-170$ & 1 & ${ }^{3} 1,000$ \\
\hline Beryllium & $0 / 12$ & $*$ & 1 & ${ }^{3} 4$ \\
\hline Cobalt & $0 / 12$ & $*$ & 1 & - \\
\hline Iron & $21 / 24$ & $4-150$ & 3 & 300 \\
\hline Manganese & $17 / 24$ & $1-530$ & 1 & 50 \\
\hline Molybdenum & $0 / 12$ & $*$ & 1 & - \\
\hline Uranium & $7 / 12$ & $1-2$ & 1 & 1,500 \\
\hline \multicolumn{5}{|c|}{ Nutrients (mg/L) } \\
\hline Ammonia, ionized + un-ionized, dissolved, as $\mathrm{N}$ & $3 / 24$ & $0.02-0.22$ & 0.01 & - \\
\hline Ammonia, un-ionized (calculated), dissolved, as $\mathrm{N}$, & $3 / 24$ & $0.0009-0.004$ & - & 0.02 \\
\hline Nitrite, dissolved, as $\mathrm{N}$ & $0 / 24$ & $*$ & 0.01 & 0.05 \\
\hline Nitrate, dissolved, as $\mathrm{N}$, & $19 / 24$ & $0.05-0.61$ & 0.05 & 10 \\
\hline Ammonia plus organic nitrogen, dissolved, as $\mathrm{N}$ & $1 / 24$ & 0.5 & 0.2 & - \\
\hline Orthophosphate, dissolved, as P & $5 / 24$ & $0.05-0.08$ & 0.01 & - \\
\hline Phosphorus, dissolved, as $\mathrm{P}$ & $6 / 24$ & $0.02-0.09$ & 0.01 & - \\
\hline Total phosphorus as $\mathrm{P}$ & $5 / 24$ & $0.06-0.10$ & 0.01 & - \\
\hline
\end{tabular}

${ }^{1}$ Colorado Department of Health (1996): standards are for Gore Creek.

${ }^{2}$ U.S. Environmental Protection Agency (1994).

${ }^{3}$ Stream standard is for total recoverable material.

\section{TRACE ELEMENTS}

Concentrations of trace elements did not exceed the stream standards established by the Colorado Department of Health (Colorado Department of Health, 1996), except for manganese at site 14 (fig. 1), where Black Gore Creek flows into Black Lake. The locations where samples for trace elements were collected are shown in figure 1.

Four of the USEPA trace-element priority pollutants (U.S. Environmental Protection Agency, 1994) listed in table 1 were detected at low concentrations. They are, in descending order of detection frequency, nickel, zinc, chromium, and copper. Zinc had the highest concentration, 5 micrograms per liter $(\mu \mathrm{g} / \mathrm{L})$, of the four priority trace elements detected. Zinc and copper concentrations were highest at the background site on G ore Creek (site 1 ), indicating that weathering of crystalline rock in the headwaters was the source of these elements. Priority trace elements that were not detected in the watershed were arsenic, cadmium, lead, and silver.

Five other dissolved trace elements-aluminum, barium, iron, manganese, and uranium-were detected during the low-flow synoptic sampling (table 1). The highest manganese concentrations were on Black Gore Creek; concentrations ranged from $530 \mu \mathrm{g} / \mathrm{L}$ at site 14 , the farthest upstream site on Black Gore Creek, to $22 \mu \mathrm{g} / \mathrm{L}$ at site 18 , just upstream from the confluence with Gore Creek. Weathering of sedimentary rock greatly contributes to these elevated manganese concentrations (Steele and others, 1991). The two lakes on Black Gore Creek downstream from site 14 probably removed most of the manganese from the creek through precipitation and deposition processes. All other manganese concentrations in the watershed were less than $20 \mu \mathrm{g} / \mathrm{L}$. The pattern for iron concentrations in the watershed was similar to the pattern for manganese; the highest iron concentrations $(14,20$, and $150 \mu \mathrm{g} / \mathrm{L})$ were in Black Gore Creek, and all other iron concentrations were less than $10 \mu \mathrm{g} / \mathrm{L}$. Aluminum and barium were detected in all analyses, but each of these detections was less than stream standards (table 1). Dissolved uranium was detected 7 times in low concentrations ranging from 1 to $2 \mu \mathrm{g} / \mathrm{L}$. Antimony, beryllium, cobalt, and molybdenum were not detected.

Weathering of crystalline and sedimentary rocks seemed to be the primary source of dissolved trace elements in the watershed. Land uses associated with urban development and recreation did not measurably affect concentrations of trace elements in Gore Creek during the synoptic sampling. 


\section{NUTRIENTS}

Nutrient concentrations did not exceed applicable stream standards in the Gore Creek watershed. Because ammonia is reported as ionized plus unionized ammonia, but only the un-ionized part of ammonia is considered harmful to fish and has a stream standard, the ammonia and the calculated un-ionized ammonia concentrations (Thurston and others, 1974) are listed individually in table 1. The highest concentration for ammonia was just $0.22 \mathrm{mg} / \mathrm{L}$ at site 14 , the farthest site upstream on Black Gore Creek. Un-ionized ammonia concentrations were very low in the watershed.

Nitrate concentrations in the main stem of Gore Creek gradually increased from $0.07 \mathrm{mg} / \mathrm{L}$ as $\mathrm{N}$ at the background site (site 1) to $0.17 \mathrm{mg} / \mathrm{L}$ as $\mathrm{N}$ at site 8 upstream from the wastewater-treatment-plant outfall (fig. 4). This slight increase occurs as Gore Creek flows past the golf course and through areas draining increasingly urban land uses. Concentrations of nitrate and other nutrients were less than the applicable stream standards downstream from the treatment-plant outfall. However, figure 4 shows the somewhat elevated concentrations of nitrate and total phosphorus at the Gore Creek sites downstream from site 8 and the treatment-plant outfall.

Nitrate and total phosphorus concentrations in Gore Creek were fairly low when compared to data compiled for a study of regional and national nutrient-concentration patterns (Mueller and others, 1995). The concentrations in Gore Creek were comparable to concentrations measured in streams draining mostly undeveloped areas.

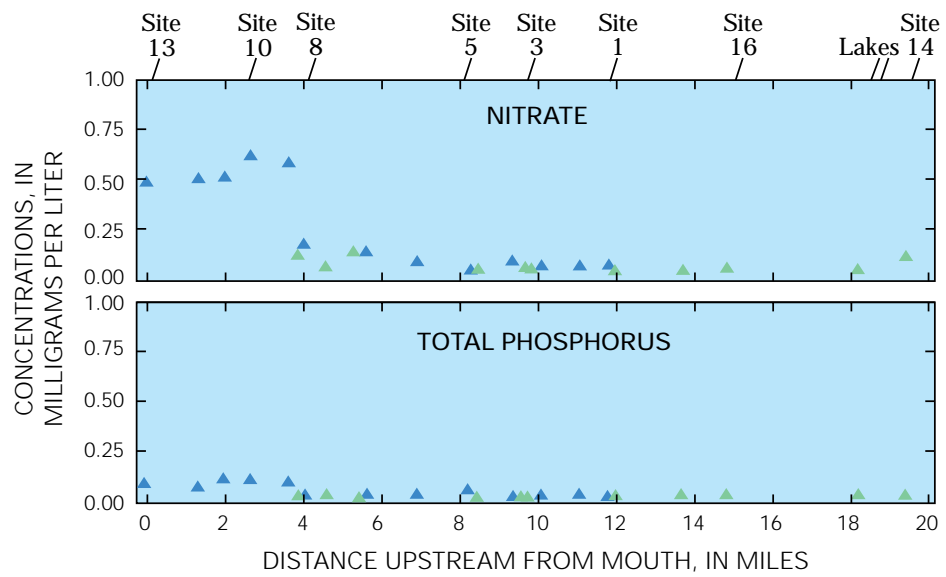

Figure 4.-Concentrations of selected constituents. Symbol colors correspond to explanation in figure 1.

\section{SUMMARY}

Surface water in the Gore Creek watershed was of good quality during the summer low-flow synoptic sampling. Recreational and urban land uses did not substantially affect water quality. Weathering of rocks seemed to be the primary source of dissolved-solids and trace-element concentrations in the watershed. Zinc and copper were highest at site 1 on Gore Creek, which drains igneous, crystalline bedrock. Tributaries draining sedimentary rocks had the higher concentrations of manganese, iron, and dissolved solids. Nutrient concentrations increased in a downstream direction through the Town of Vail, but remained relatively low.

Results of the synoptic sampling indicate that the stable summer low-flow period is a time of good water quality in the watershed-dissolved-oxygen concentrations are high, and constituent concentrations are low. Additional data collected during higher flow runoff events, such as snowmelt or thunderstorms, would be beneficial in evaluating effects of land use on water quality.

\section{REFERENCES}

Apodaca, L.E., Driver, N.E., Stephens, V.C., and Spahr, N.E., 1996, Environmental setting and implications on water quality, Upper Colorado River Basin, Colorado and Utah: U.S. Geological Survey WaterResources Investigations Report 95-4263, 33 p.

Colorado Department of Health, 1996, Classifications and numeric standards for U pper Colorado River Basin and North Platte River (planning region 12) 3.3.0: Denver, Water Q uality Control Commission, 72 p.

Crowfoot, R.M., Paillet, A.V., Ritz, G.F., Smith, M.E., J enkins, R.A., and O'Neill, G.B., 1996, Water resources data, Colorado, water year 1996 , v. 2, Colorado River Basin: U.S. Geological Survey WaterData Report C 0-96-2, $551 \mathrm{p}$.

Leahy, P.P., Rosenshein, J.S., and Knopman, D.S., 1990, Implementation plan for the National Water-Q uality Assessment Program: U.S. Geological Survey Open-File Report 90-174, 10 p.
Mueller, D.K, Hamilton, P.A., H elsel, D.R., Hitt, K.J ., and Ruddy, B.C., 1995 Nutrients in ground water and surface water of the U nited StatesAn analysis of data through 1992: U.S. Geological Survey WaterResources Investigations Report 95-4031, 74 p.

Shelton, L.R., 1994, Field guide for collecting and processing stream-water samples for the National Water-Q uality Assessment Program: U.S. Geological Survey O pen-File Report 94-455, 42 p.

Spahr, N.E., Driver, N.E., and Stephens, V.C., 1996, The Upper Colorado River National Water-Q uality A ssessment Program surface-watermonitoring network: U.S. Geological Survey Fact Sheet 191-96, 4 p.

Steele, T.D., Weaver, R.M., and Mott, D.E., 1991, Temporal and spatial patterns in trace-metal concentrations of a mountain stream in westcentral Colorado, USA, in Peters, N.E., and Walling, D.E., eds., Sediment and stream water quality in a changing environment; trends and explanation-Proceedings of symposium, International U nion of Geodesy and Geophysics, Vienna, Austria, August 11-24, 1991: International Association of Hydrological Sciences Publication 203, p. 293-302.

Thurston, R.V., Russo, R.C., and Emerson, Kenneth, 1974, Aqueous ammonia equilibrium calculations: B ozeman, Montana State U niversity, Fisheries Bioassay Laboratory Technical Report 74-1, 18 p.

U.S. Environmental Protection Agency, 1994, Water quality standard hand book ( 2 d ed.): U.S. Environmental Protection A gency Report EPA-823-B-94-005b, appendix p, 3 p.

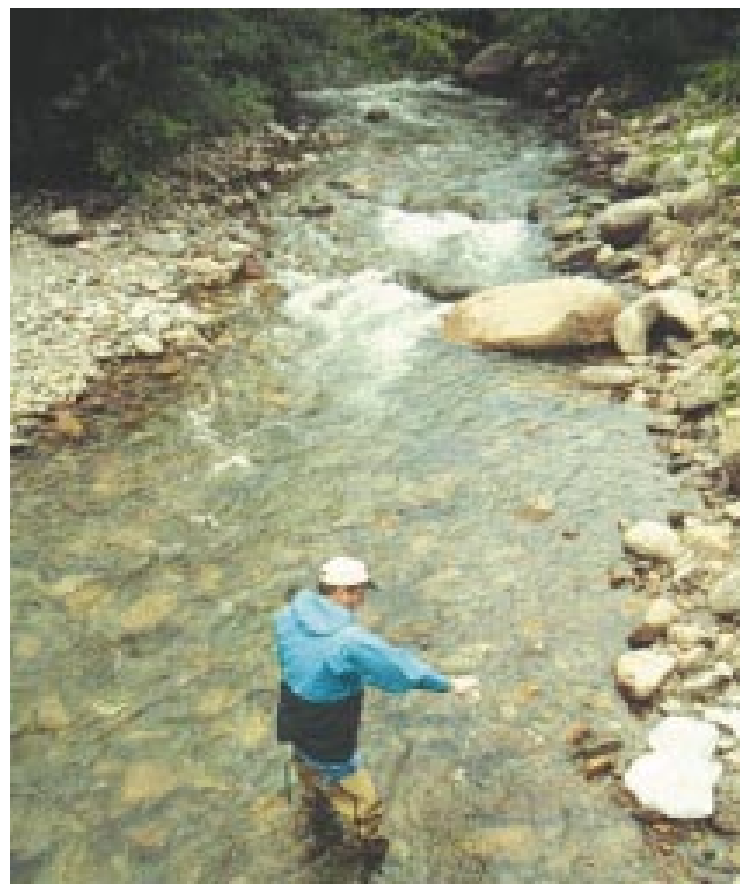

Photograph by Richard J . Szmajter

Information on technical reports and hydrologic data related to the NAWQA program can be obtained from:

Upper Colorado River NAWQA Manager U.S. Geological Survey, Water Resources Division

Bldg. 53, Denver Federal Center Mail Stop 415, Box 25046 Denver, CO 80225-0046

email: nedriver@usgs.gov

Manuscript and Layout: Alan M. Duran

Design: Alan M. Duran, Loretta J. Ulibarri, and Anthony Sanchez

Final illustrations: Alan M. Duran and Anthony Sanchez 